\title{
Corticosterone Metabolism and the Incorporation of Leucine, Uridine, and Thymidine into Fetal Mouse Brain
}

\author{
LESLEY M. TYE, NICOLE J. MICHAUD, AND A. F. BURTON \\ Department of Biochemistry, University of British Columbia, Vancouver, British Columbia, \\ Canada V6T IW5
}

\section{Summary}

The change in the pattern of biotransformation of $\left[{ }^{14} \mathrm{C}\right]$ corticosterone in fetal mouse brain between gestational days 14 and 17 increased the proportion of unchanged hormone from $9-75 \%$. A sharp decrease in the in vitro incorporation of $\left[{ }^{14} \mathrm{C}\right]$ leucine, $\left[{ }^{3} \mathrm{H}\right]$ uridine, and $\left[{ }^{3} \mathrm{H}\right]$ thymidine into incubated brain coincided with this change and continued until day 19 , when the incorporation of the 3 substrates had fallen to 9,54 , and $16 \%$, respectively, of that on day 14. Injection of dexamethasone reduced values on day 14 to those normally found on days 15-18. Enzymes which metabolize corticosteroids regulate their activity in specific tissues; these data suggest a hormonal influence on developing brain.

\section{Speculation}

Corticosteroids are known to induce metabolic processes in a number of fetal tissues; the brain can be included in these. These changes are mediated by enzymes in that tissue and do not necessarily involve the fetal pituitary-adrenal axis, nor the pattern of glucocorticoid receptors. 


\section{Introduction}

Examination of the disposition of corticosteroids in the mouse fetus had led us to the concept that, since these hormones in their regulation is the activity of enzymes in specific tissues which metabolize them (10). This communication describes the relationship between the metabolism of corticosterone in fetal mouse brain and its effects on the brain as determine in fetal incorporation of ${ }^{1}{ }^{4} \mathrm{C}-$-leucine, ${ }^{3} \mathrm{H}$-thymidine and ${ }^{3} \mathrm{H}$-uridine.

\section{Materials and Methods}

\section{CHEMICALS}

Radioactive compounds purchased from New England Nuclear Corp. (Boston) included dexamethasone-1,2,4-3 $\mathrm{H}, 21.2 \mathrm{Ci} / \mathrm{mmol}$, $\mathrm{mCi} / \mathrm{mmol}$, uridine $-4-{ }^{3}{ }^{4} \mathrm{C}, 57.3 \mathrm{mCl} / \mathrm{mmol}$. L-leucine-14 $\mathrm{C}(\mathrm{U}), 331$ $\mathrm{Ci} / \mathrm{mmol}$ were obtained from Amersham/Searle, Arlington Heights, IL.

The non-radioactive dexamethasone used was a gift from Merck
Co. (Rahway, NJ). The ll-epicorticosterone and Co. (Rahway, NJ). The ll-epicorticosterone was kindly sup-
plied by Dr. J.C. Babcock, The Upjohn Company, (Kalamazoo, MI).

All solvents used were distilled freshly before use.

\section{EXPERTMENTAL ANIMALS}

Non-inbred Swiss mice were raised at the Zoology Department Vivarium at this university. Matings were between 1800 and 0700 $\mathrm{hr}$. If a plug was found in the morning, that day was designated gestational day 1 . Mice were killed with excess $\mathrm{CO}_{2}$ and the fetuses were removed and decapitated quickly and placed on a petri $25 \mathrm{ml}$ erlenmeyer Tissues were minced with scissors and placed in a $25 \mathrm{ml}$ erlenmeyer flask to which buffer and substrates were added. at 120 cycles/min. In earlier work $(10),{ }^{3} \mathrm{H}$-corticosterone and
at 列 reduction in tissues. The ratio of reduction/dehydrogenation in head on gestational day 14 for example, was 0.12 . In the present work, ${ }^{14} \mathrm{C}$-corticosterone of co was used, since it reflects, fairly well, the net conversion onstration of other metabolites.

INCUBATIONS

Incubations for following the in vitro metabolism of ${ }^{14} \mathrm{C}$ corticosterone included $5 \mathrm{nci}$ corticosterone $-4-1{ }^{4} \mathrm{C}$ with 2 or 3 fetal heads finely minced, in $1 \mathrm{ml}$ Krebs-Eggleston phosphate buffer $\mathrm{pH} 7.4$ for $15 \mathrm{~min}(6)$. The mixture was then extracted with 6 vol n-hexane, which was discarded and then with 6 vol cold $\mathrm{CH}_{2} \mathrm{Cl}_{2}$, which was evaporated under $\mathrm{N}_{2}$ and spotted, either onto a silica gel TLC sheet for autoradiography, or onto Whatman no. 1 paper if quantitative recovery was required. The TLC sheets were
developed in two solvent systems; (I) hexane:ethyl acetate (4:1, developed in two solvent systems; (I) hexane:ethyl acetate $(4: 1$
$v: v)$, and (2) toluene: chloroform:methanol:water (120:60:20:1, v:viv:v). The paper chromatography was performed using $20: 1$, impregnated with formamide: methanol $(1: 1, v: v)$ and developed in

Samples of 2 or 3 fetal heads were minced finely, and incubated in $1 \mathrm{ml}$ Krebs-Eggleston bicarbonate buffer $\mathrm{pH} 7.4$ (6), containing $0.14 \mu \mathrm{Ci}$ leucine ${ }^{14} \mathrm{C}(\mathrm{U}), 0.46 \mu \mathrm{Ci}{ }^{3} \mathrm{H}$-uridine, or 0.46 in a water bath shaking at 120 werc carried out for 1 hr at $37^{\circ} \mathrm{C}$ in a water bath shaking at 120 cycles/min. In some experiment arately. and the metabolism of corticosterone was demonstrable in isolated
brain. Because of the difficulty in separating the tissues cleanly, however, experiments were routinely carrie tissues whole heads. The samples were were routinely carried out using omnimixer (Ivan Sorvall Inc, Newtown, CT). An aliquot of $0.1 \mathrm{ml}$ was removed for protein determinations by the method of Lowry, Rosebrough, Farr and Randall (9). Then 0.1 vol 308 trichloroacetic acid (TCA) was added. The precipitate was washed 4 times with $3 \mathrm{mI} 38 \mathrm{TCA}$, then solubilized in BBS-3 solubilizer (Beckman Instruments, Fullerton, CA). The sample was mixed with scintillation fluid (Econofluor, New England Nuclear, Boston, MA) and counted in a Unilux IIA liquid scintillation spectromete (Nuclear/Chicago, Chicago, IL). Quenching was determined by the method of external standards ratios.

The assay for corticosteroid receptors in fetal mouse brain in the same manner as was done for placenta (13). The $105,000 \mathrm{xg}$ supernatant of brain was incubated for $30 \mathrm{~min}$ on ice with $8 \mathrm{nM}(0.33 \mu \mathrm{Ci}) \mathrm{H}$-dexamethasone and the unbound steroid was removed by addition of dextran-coated charcoal. In these of the non-specific binding, while not displacing the specifically bound hormone (13).

\section{Results}

The change in the pattern of biotransformation of corticosterone in fetal mouse brain incubated in vitro between gestational days 15 and 17 is shown in Fig. 1. Even between morning, after noon and evening of day 15 there appeared to be differences in to $75 \%$ of the total recovered counts. Other metabolites decreased
sharply on day 15 .

Characterization of corticosterone and ll-dehydrocorticosterone has been described (10). The fastest moving zone was identified by co-crystallization with authentic added carrier as 1l-dehydrocorticosterone acetate, and the zone directly behind it as corticosterone acetate. The slower moving derivatives have li-dehydrocorticosterone and corticosterone (the slowest zone).
Reference $20 \alpha$-dihydro compounds were prepared by incubating nonradioactive corticosterone with a dialyzed $105,000 \mathrm{xg}$ supernatant chromatographically, as described by Krehbiel (7). The radioactivity of the metabolites and theix acetate derivatives coincided during chromatography with the UV absorbance of the added reference compounds and could be distinguished from
their $20 \mathrm{~B}$ isomers.

The increase in proportion of unchanged hormone suggested that it might have a role in brain function at this time. This prompted a search for specific steroid receptors which might indizate that tabrain is a "target" tissue. The findings are summarized in Table 1. As in previous work with placenta (13), evidence
for such a factor(s) was obtained; values of $\mathrm{K}_{\mathrm{d}}=8.33 \mathrm{nM}$ and 0.14 pmoles steroid bound per mg protein were determined on gestational day 14. The concentration of receptors did not increase thereafter, and, in fact, with continued growth of the brain the thereafter, and, in fact, with continued growth of the brain the lability of the receptors, the presence of dithiothreitol did not increase binding in tissues on gestational day 19.

As seen in Table 2, the incorporation of ${ }^{14} \mathrm{C}$-leucine, ${ }^{3} \mathrm{H}-$ uridine and ${ }^{3} \mathrm{H}$-thymidine began to fall at the time the change in corticosterone conversion occurred. This decrease continued until day 19, when the values for these 3 substrates had fallen to 9,54 and 168 , respectively, of those on day 14 . In order to steroid, mothers were injected on day $13.5 \mathrm{with} 200 \mathrm{\mu g}$ dexamethasone. As indicated in Table 2, the synthetic steroid decreased values on gestational day 14 for all substrates to those normally Discussion

of the metabolites of corticosterone found in fetal mouse brain (Fig. 1), the $\mathrm{C}-20$ dihydro derivatives are known to be biologically inactive, whereas acetate conjugates and C-ll ketone derivatives can be converted to corticosterone in tissues which contain the appropriate enzymes (4). The formation of acetate esters is not a common finding, but has been reported in the
brain of two other species (5). The most striking change observed was the sharp increase in the relative amount of the biologically active component, coxticosterone. Since the concentration of steroid receptors did not increase (Table 1), it seems most likely that it is the increased hormone concentration in the tisthis time.

The sharp decrease in the incorporation of labelled substrates into the acid-insoluble components of fetal brain (Table 2) coincided with the decrease in the rate of corticosterone conversion, and continued for several days. That this event is in the fact that injection of dexamethasone on gestational day 13.5 the fact that injection of dexamethasone on gestational day 13.5 resulted in values on day 14 which were normally found between
days 15 and 18 (Table 2 ). The synthetic steroid was used here because it largely escapes the normal regulatory mechanisms which protect the fetus from maternal corticosteroids, wit
that a more effective dose reaches the fetus (14).

A relationship similar to that described here has been reported in fetal rabbit lung, where induction of phospholipid synthesis by cortisol was related to reductase activity which converts cortisone to cortisol (11). Inhibition of this reaction by 11-ketoprogesterone was shown to inhibit lung maturation in fetal rats (12). In a similar manner, inhibition of the dehydrogenase reaction by ll-epicorticosterone enhanced the action of corticosterone as measured by glycogen deposition in neonatal
mice (1). These experiments provide direct evidence that enzymes in a tissue which metabolize corticosteroids influence their. biological activity in the same and probably also in other tis-
sues. It should be noted that these events can occur in specific sues. It should be noted that these events can occur in specif
fetal tissues independently, without necessarily involving the fetal tissues independently, with
fetal pituitary and/or adrenal.

Morphological studies have not revealed any significant differences evident by light microscopy, at least within the 16 hours following dexamethasone treatment; further examination is in progress (15). Corticosteroid-induced maturation of rat and rabbit lung was accompanied by decreased growth and cell division in lung tissue $(3,12)$. Such effects are suggested by the para-
meters which were measured here as a reflection of growth.

The introduction of corticosteroid therapy administered prenatally the lung in premature infants This effect on the have caused other deleterious effects (8). results such as those described herein implicate corticosteroids in several critical roles but at a much earlier stage in fetal development. However, the presence of the 11 B-reductase in human fetal liver as early as 20 weeks (2), raises the liklihood that similar events occur in
during the last trimester.

\section{References}

1. Burton, A.F., Greenall, R.M. and Turnell, R.W.: Corticosteroid metabolism and liver glycogen in fetal and newborn mice. Can. J. Biochem. 48: 178 (1970)

2. Burton, A.F., Mcclellan, D.J., Drummond, M.R., Mah, T.G., Thomson, M.J., Wong, W. and Turnell, R.W.: Corticosteroid in premature cord blood determined fluorometrically by Metab. 39: 950 (1974).

3. Carson, S.H., Taeusch, H.W. and Avery, M.E.: Inhibition of lung cell division after hydrocortisone injection into fetal rabbits. J. Appl. Physiol. 34: 660 (1973).

Fieser, L.F, and Fieser, M.: Steroids, Reinhold Publishing 
5. Grosser, B.I. and Axelrod, L.R.: Acetylation of cortisol by neonatal rat brain in vitro. Steroids 9: 229 (1967).

6. Krebs, H.A. and Eggleston, L.V.: The oxidation of pyruvat in pigeon

. Krehbiel, R.E., Burton, A.F. and Darrach, M.: Studies on corticosterone $\mathrm{C}-20$ reduction in the mouse. Can. J. Biochem.

8. Liggins, G.C. and Howie, R.N.: A controlled trial of antepartum glucocorticoid treatment for prevention of the respiratory distress syndrome in premature infants. Pediatric

9. Lowry, O.H., Rosebrough, N.J., Farr, A.L. and Randall, R.R.: Protein measurements with the Fol in phenol reagent. Biol. Chem. 193: 265 (1951).

10. Michaud, N.J. and Burton, A.F.: Maternal-fetal relationships

1. in corticosteroid metabolism. Biol. Neonate 32: 132 (1977) different gestation-d.s. and Giroud, c.J.P. Evidence for tured fetal lung cells. J. Clin. Invest. 53: 1518 (1974).

. Smith, B.T.: The role of pulmonary corticosteroid ll-reductase activity in lung maturation in the fetal rat. Pediat. Res. I2: 12 (1978)

13. Wong, M.D and Burton, A.F.: Studies on corticosterone-receptor complexes from mouse placenta. Can. J. Biochem. 52: 190 (1974).

14. Wong, M.D., Thomson, M.J. and Burton, A.F.: Metabolism of natural and synthetic corticosteroids in relation to their effects on mouse fetuses. Biol. Neonate 28: 12 (1976)

15. The authors are grateful to Dr. Mary E. Todd, Dept. of Anatomy, for microscopic examination of tissue samples.

16. Received for publication March 20, 1978.
17. Accepted for publication June 8, 1978.

Table 1. Properties of corticosteroid receptor(s) in fetal mouse brain.

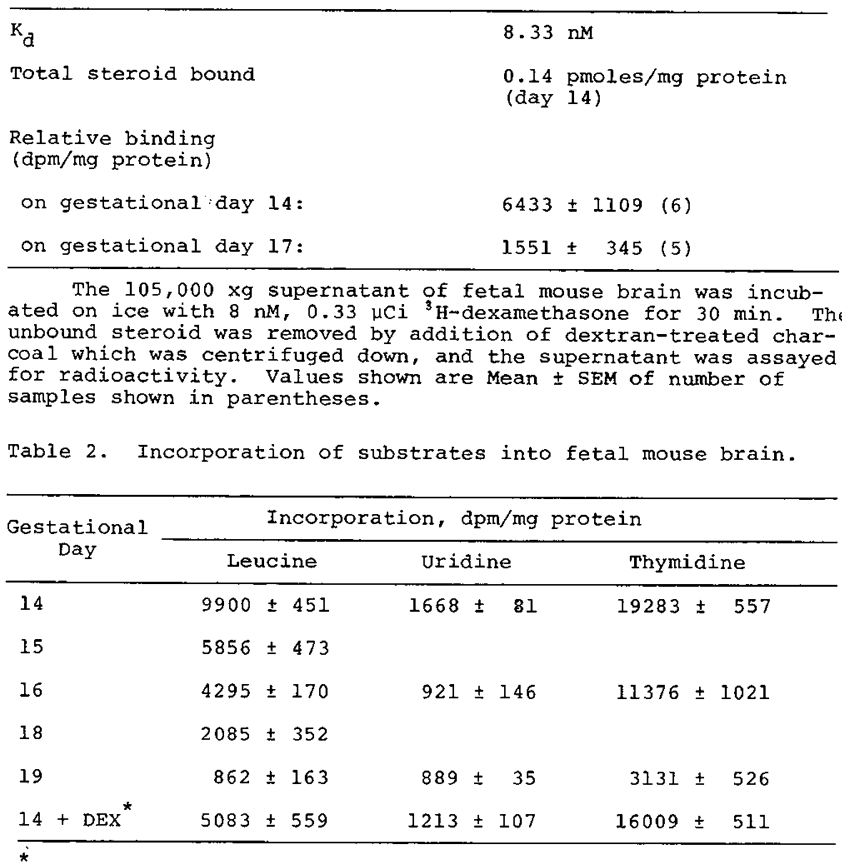

* Dexamethasone, $200 \mu \mathrm{g}$, was injected subcutaneously $16 \mathrm{hr}$ earlier
Two or three fetal heads were pooled and incubated in $1 \mathrm{ml}$ buffer containing $2 \mathrm{mg}$ glucose at $37^{\circ}$ for $60 \mathrm{~min}$, with either $0.24 \mu \mathrm{Ci}$ leucine ${ }^{1} \mathrm{C}$, or $0.46 \mu \mathrm{Ci}$ uridine ${ }^{3} \mathrm{H}$ or thymidine ${ }^{3} \mathrm{H}$. Each sample was then homogenized and an aliquot removed for protein determination, and 0.1 vol $30 \%$ TCA was added. The precipitates were washed $4 \mathrm{x}$ with $38 \mathrm{TCA}$, then solubilized and counted. Each value is a mean \pm SEM of 4 or more values from several litters. Day 14 vs Day $16:$ P $<0.01$ in all cases; Day 14 vs Day $14+$ DEX: $P<0.01$ in all cases.

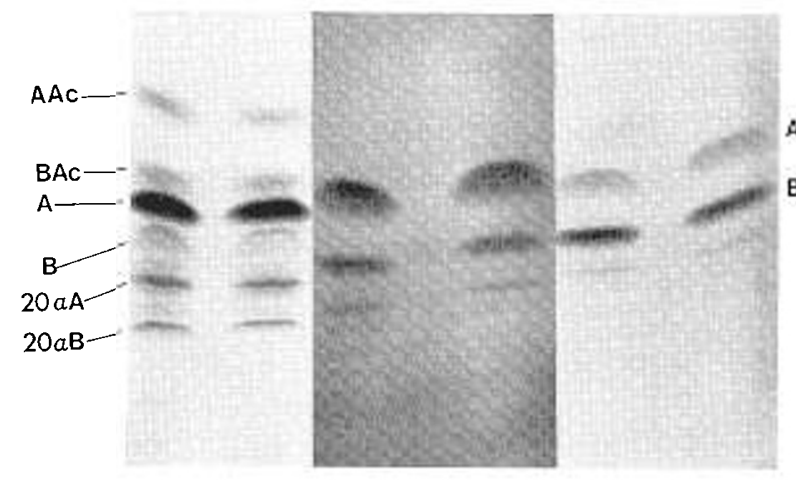
1
2
3
4
5
6

Fig. 1. Autoradiograms of chromatographed extracts of tissues incubated with ${ }^{1}{ }_{4} \mathrm{C}$-corticosterone. $\mathrm{CH}_{2} \mathrm{Cl}_{2}$ extracts were spotted anto slica gel TLC sheets and developed in first, hexane:ethy 1 $60: 20: 1)(4: 1)$ and second, toluene:chloroform:methanol:water (120 $14 ; 3$ \& 4 : day $15 ; 5$ \& $6:$ day 14 are:

AAC: 11-dehydrocorticosterone acetate

BAC: corticosterone acetate

A: 11-dehydrocorticosterone

B: corticosterone

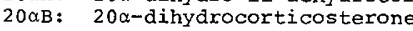

Note the increase in size of the $B$ zone and decrease in size of the $A$ zone in 3 to 6 , as compared with 1 and 2 . The $B$ zone increased from 98 on day 14 to 758 of the total counts on day 17 